\title{
Sepsis and Myocardial Dysfunction: A Mini Review
}

\author{
Sushilkumar Satish Gupta ${ }^{1 *}$, Vinod Namana ${ }^{2}$ and Yizhak Kupfer ${ }^{3}$ \\ ${ }^{1}$ Department of Internal Medicine, Maimonides Medical Center, USA \\ ${ }^{2}$ Department of Cardiology, Maimonides Medical Center, USA \\ ${ }^{3}$ Department of Pulmonary and Critical Care Medicine, Maimonides Medical Center, USA
}

Submission: March 20, 2017; Published: April 17, 2017

*Corresponding author: Sushil kumar Satish Gupta, Internal Medicine Resident, Division of Internal Medicine, Maimonides Medical Center, 4802 10th Avenue, Brooklyn, NY, 11219, USA, Fax: 718283 8498; Tel: 718283 6000; Email: sugupta@maimonidesmed.org

Abstract

Sepsis is one of the leading causes of mortality and morbidity around the world. Myocardial dysfunction is one of the important factors in the hemodynamic compromise seen in sepsis. Numerous mechanisms have been studied in identifying the pathophysiology, however, no definitive hypothesis has been proven. This review attempts to evaluate, and understand some of the known biochemical and pathophysiological mechanisms leading to cardiac dysfunction and sepsis.

\section{Introduction}

Sepsis is the leading cause of mortality and a major healthcare concern worldwide [1]. It is characterized as a life-threatening disease, enhanced by a dysregulated immune host response to a precipitating infection. It's a multifaceted disease, encompassing various organs and may lead to endorgan failure, shock and death. In a healthy human being the pro-inflammatory response triggered by microbes is countered by the body's anti-inflammatory mechanism; however, during sepsis this mechanism gets dysregulated, leading to organ failure.

The association of sepsis and the cardiovascular system has been studied over a period of several decades; however, the exact pathophysiology remains unclear. Myocardial depression is defined as cardiac output that fails to meet the body's metabolic demands [2,3]. Approximately $15 \%$ of the deaths related to septic shock are due to myocardial depression [3].

\section{Myocardial Dysfunction Factors}

\section{Global ischemia}

In septic shock, there is a significant change in the microcirculatory system including peripheral vascular dysfunction, endothelial damage and induction of the coagulation cascade which can result in heterogeneous microcirculatory flow. Septic shock is a form of distributive shock, characterized by circulatory abnormalities that are usually related to intravascular volume depletion and vasodilation, resulting in oxygen supply-demand mismatch and end-organ damage [4]. Studies in animal models showed that cardiac dysfunction occurs if the initial resuscitation is inadequate [5]. Therefore, earlier theories suggested that global myocardial ischemia could be responsible for myocardial dysfunction in sepsis. However, in 1986, Cunnion et al. [6] performed studies on coronary sinus catheterization, which demonstrated that coronary flow was the same or greater in early septic shock patients when compared to normal individuals. Therefore, the observed myocardial dysfunction associated with sepsis is not related to abnormal coronary blood flow and development of coronary ischemia, proving that global ischemia is not the reason for myocardial dysfunction in sepsis. However, it may still be true that abnormal coronary blood flow may play a role in myocardial dysfunction in patients with the pre-existing atherosclerotic disease.

\section{Endotoxins}

Endotoxins are also believed to play a crucial role in causing cardiac dysfunction. They interact with the cell membrane receptor, known as Toll-like receptor4 (TLR4) found in the cardiac immune cells. Endotoxins such as lipopolysaccharides (LPS), lipoteichoic acid, mannan in fungi, RNA in viruses interact with TLR- 4 and initiate inflammation through mediators such as interleukins, cytokines, nitric oxide (NO), and C5 [7]. Although these inflammatory changes have 
been clearly demonstrated in gram negative sepsis, there is minimal data in gram-positive sepsis. Thus, while endotoxins and inflammation may play a role, it is not the only cause of myocardial dysfunction in sepsis.

\section{Myocardial depressant factor}

Myocardial depressant factors (MDF) are also believed to play a part in causing cardiac dysfunction in sepsis. In the mid-1970s, Lefer \& Martin [8] highlighted the presence of an MDF in the blood of dogs during induced endotoxic shock and suggested that it was a peptide of 800 to 1,000 daltons that originated in the pancreas. Since then numerous MDF such as interleukins 1 , and 6, tumor necrosis factor- $\alpha$ (TNF- $\alpha$ ), complement anaphylatoxin ( $\mathrm{C} 5 \mathrm{a})$, High mobility group box 1(HMGB1), extracellular histones, matrix metalloproteinase-9 (MMP 9) have been identified and reported in the literature [9]. TNF- $\alpha$ and interleukins are considered to be the most important myocardial depressive factors. In an inflammatory state, TNF- $\alpha$ is usually released from the activated macrophages but, Horton et al showed that TNF- $\alpha$ is also released by the cardiac myocytes in response to sepsis [10]. Monoclonal antibodies directed against TNF- $\alpha$ are believed to improve the left ventricular function; however, they failed to improve survival in patients with sepsis [11,12]. IL-1 alters the cardiac contractility by stimulating the release of nitric oxide synthase (NOS) [13]. The roles of recombinant IL-1 receptor antagonist have been studied, but to date, it has failed to show statistically significant benefit in patients with sepsis [14].

Thus, a multitude of factors, rather than any individual factor are responsible for the onset of sepsis-induced myocardial dysfunction. More prospective studies are needed to elucidate their roles and provide a substrate for future therapeutic interventions.

\section{Treatment}

Cardiac dysfunction in sepsis is believed to be multifactorial; therefore it is vital to identify individual receptors and molecules, so as to develop targeted therapeutic agents. Currently, supportive measures including intravenous crystalloid infusion, broad-spectrum antibiotics, surgical intervention if required to remove the septic foci, and close monitoring in an intensive care unit are the mainstay of treatment. As per the recent surviving sepsis guidelines, aggressive intravenous hydration with crystalloid solution of at least $30 \mathrm{~mL} / \mathrm{kg}$ should be given within the first 3 hours in patients with septic shock to maintain mean arterial pressure $\geq 65 \mathrm{mmhg}$ and inotropic support be given to patients not responding to the initial aggressive hydration [15]. One should also be vigilant while administering intravenous fluids as the excessive fluid administration may lead to pulmonary edema due to increased permeability of the microcirculation and cardiac dysfunction, associated with sepsis.

\section{Conclusion}

Prompt recognition of the source of sepsis is of prime importance. Treatment is mainly supportive comprising of aggressive hydration, inotropic support for patients in septic shock, broad spectrum antibiotics, and close monitoring of cardiac hemodynamics in an intensive care setting. A multidisciplinary approach should be maintained. We will need more prospective studies to understand the depth of interaction between sepsis and myocardial dysfunction.

\section{References}

1. Centers for Disease Control (1990) Increase in National Hospital Discharge Survey rates for septicemia-United States, 1979-1987. MMWR Morb Mortal Wkly Rep 39(2): 31-34.

2. Rivers E, Nguyen B, Havstad S, Ressler J, Muzzin A, et al. (2001) Early goal-directed therapy in the treatment of severe sepsis and septic shock. N Engl J Med 345(19): 1368-1377.

3. Parrillo JE (1989) The cardiovascular pathophysiology of sepsis. Annu Rev Med 40: 469-485.

4. Hotchkiss RS, Karl IE (1992) Reevaluation of the role of cellular hypoxia and bioenergetic failure in sepsis. JAMA 267(11): 1503-1510.

5. Coalson JJ, Hinshaw LB, Guenter CA, Berrell EL, Greenfield LJ (1975) Pathophysiologic responses of the subhuman primate in experimental septic shock. Lab Invest 32(4): 561-569.

6. Cunnion RE, Schaer GL, Parker MM, Natanson C, Parrillo JE (1986) The coronary circulation in human septic shock. Circulation 73(4): 637644.

7. Russell JA, Boyd J, Nakada T, Thair S, Walley KR (2011) Molecular mechanisms of sepsis. Contrib Microbiol 17: 48-85.

8. Lefer AM, Martin J (1970) Origin of myocardial depressant factor in shock. Am J Physiol 218(5): 1423-1427.

9. Lv X, Wang H (2016) Pathophysiology of sepsis-induced myocardial dysfunction. Mil Med Res 3: 30.

10. Horton JW, Maass D, White J, Sanders B (2000) Nitric oxide modulation of TNF-alpha-induced cardiac contractile dysfunction is concentration dependent. Am J Physiol Heart Circ Physiol 278(6): H1955-H1965.

11. Abraham E, Anzueto A, Gutierrez G, Tessler S, San Pedro G, et al. (1998) Double-blind randomised controlled trial of monoclonal antibody to human tumour necrosis factor in treatment of septic shock. Lancet 351(9107): 929-933.

12. Fisher CJ, Agosti JM, Opal SM, Lowry SF, Balk RA, et al. (1996) Treatment of septic shock with the tumor necrosis factor receptor: Fc fusion protein. The Soluble TNF Receptor Sepsis Study Group. N Engl J Med 334(26): 1697-1702.

13. Francis SE, Holden H, Holt CM, Duff GW (1998) Interleukin-1 in myocardium and coronary arteries of patients with dilated cardiomyopathy. J Mol Cell Cardiol 30(2): 215-223.

14. Opal SM, Fisher CJ, Dhainaut JF, Vincent JL, Brase R, et al. (1997) Confirmatory interleukin-1 receptor antagonist trial in severe sepsis: a phase III, randomized, double-blind, placebo-controlled, multicenter trial. The Interleukin-1 Receptor Antagonist Sepsis Investigator Group. Crit Care Med 25(7): 1115-1124.

15. Rhodes A, Evans LE, Alhazzani W, Levy MM, Antonelli M, et al. Surviving Sepsis Campaign: International Guidelines for Management of Sepsis and Septic Shock: 2016. Crit Care Med 45(3): 486-552. 
(C) Commons Attribution 4.0 License

\section{Your next submission with Juniper Publishers} will reach you the below assets

- Quality Editorial service

- Swift Peer Review

- Reprints availability

- E-prints Service

- Manuscript Podcast for convenient understanding

- Global attainment for your research

- Manuscript accessibility in different formats

( Pdf, E-pub, Full Text, Audio)

- Unceasing customer service

Track the below URL for one-step submission https://juniperpublishers.com/online-submission.php 